\title{
特集 田んばのいきものをどうやって守っていくか?一水田水域における多様な生物の保全と再生一
}

\section{原著論文 ORIGINAL PAPER}

\section{休耕田を掘削して造成した湿地ビオトープにおける水生生物相}

\author{
中島 淳 $^{1) *}$ ・宮脇 崇 $^{2}$ \\ 1）福岡県保健環境研究所 $=818-0135$ 福岡県太宰府市向佐野 39 \\ 2）北九州市立大学 国際環境工学部 テ808-0135 福岡県北九州市若松区ひびきの1-1
}

Jun NAKAJIMA ${ }^{1 \text { * }}$, Takashi MIYAWAKI ${ }^{2}$ : Aquatic biota in a wetland biotope constructed by excavating fallow field. Ecol. Civil Eng. 24(1), 79-94, 2021

1) Fukuoka Institute of Health and Environmental Sciences, Mukaizano 39, Dazaifu, Fukuoka 818-0135, Japan

2) The University of Kitakyushu, Faculty of Environmental Engineering, 1-1 Hibikino,

Wakamatsu, Kitakyushu, Fukuoka 808-0135, Japan

\begin{abstract}
The changes of water environment and aquatic biota were investigated over a three-year period in an artificial wetland biotope (Tebika Biotope) constructed by excavating fallow field. We identified 93 aquatic animal species in 18 orders and 4 submerged plants, so it was thought that this biotope was effective in biodiversity conservation. There was a marked seasonality in the number of aquatic insect species, with an increase in summer (mainly in August) and a decrease in winter (mainly in February). The species number and diversity index (Shannon-Wiener's $H^{\prime}$ ) was greater at a site of still water with ecotones. On the other hand, some unique species were found in the monotonous flowing water environment. Almost all the aquatic insects identified in this biotope were found in the ponds within $2 \mathrm{~km}$ of the biotope. This suggests that the aquatic biota of an artificial wetland biotope is highly dependent on the surrounding biota, and that ecotones and diverse flow regimes are important for the conservation of biodiversity. The growth of submerged plants and changes in the number of aquatic insect species suggest that the biota of this biotope may have been adversely affected by the invasive alien species, a crayfish Procambarus clarkii, and a snail, Pomacea canaliculata.
\end{abstract}

Key words: alien species, aquatic insect, biodiversity, conservation, paddy field

\section{はじめに}

前世紀から引き続き地球上の自然環境は劣化し続けて おり, 中でも地表水の約 $2.3 \%$ とれる陸水域における 生物多様性は悪化の一途を辿っていることから，その保 全の重要性が繰り返し指摘されている (Dudgeon et al. 2006 ; Reid et al. 2019). 日本国内においてもその状況は 同様であり, 主に陸水域に生息する汽水・淡水魚類では 国内から記録されている種の約 6 割, 水生昆虫のうちゲ

2020 年 9 月 2 日受付, 2020 年 10 月 25 日受理

*e-mail: nakajima@fihes.pref.fukuoka.jp
ンゴロウ科では約 4 割, ミズスマシ科では約 6 割が，希 少種として環境省版レッドリストに掲載されている状況 にある（環境省 2020 ; 中島 2020）。また, 陸水環境の 中でも特に水田域に主に生息する種の状況は河川域など に比べてさらに危機的で，かつて身近な種として知られ たトノサマガエル Pelophylax nigromaculatus, ドジョウ Misgurnus anguillicaudatus, ミナミメダカ Oryzias latipes などはいずれも希少種となっているほか（環境省 2020）, 水生昆虫類としてょく知られる大型のゲンゴロウ属 $C y$ bister spp., タガメ Kirkaldyia deyrolli どの水田性種は 各地で地域的な絶滅が続いている（市川 2009 ; 北野ほ 
か 2011 ; 中島 2013 ; 西原 2016; 中島ほか 2020). 水 田域はもともと自然の汇濫原湿地に生息した生物が多く みられる環境で, 鳥類, 両生類, 魚類, 昆虫類, 甲殼類, 植物など多くの分類群の生息場となっている（Moore 2006 ; 日本湿地学会 2017). 特に昆虫類のうち生活史の 大部分を水中もしくは水面で生活する真水生のカメムシ 目とコウチュウ目については, 国内から記録されている 約 490 種のうち, 約 150 種が水田域を主要な生息場とし ていることが知られている (中島ほか 2020)。したがっ て, 国内の陸水環境の生物多様性保全を考える上で, 悪 化していく一方である水田域の生物多様性をどう保全し ていくかは大きな課題である.

こうした状況に対して，1999年に施行された食料・ 農業・農村基本法では第三条において「自然環境の保 全」が，2001 年に施行された改正土地改良法では第一 条に扔いて「環境との調和に配慮」が, その目的として 記述されるようになった。 さらに「農林水産省生物多様 性戦略」の公表（農林水産省 2012）,「農業に有用な生 物多様性の指標生物」の公表（農林水産省農林水産技術 会議事務局 2012）など，生物多様性と調和した水田域 形成に向けた取り組みは少しずつ進んでいる。しかしな がら, 水田域は稲作という農業の場でもあり, 高効率. 高収益の近代的な農業としての稲作の推進と生物多様性 保全の両立が困難であることも指摘されている（水谷 2007 ; 宇根 2016 ; 鬼倉ほか 2020).

そのような状況にある水田域に扔いて, 水生昆虫類を 中心とした生物多様性の保全・再生の手段として注目さ れているのが，湿地ビオトープ造成の取り組みである (養父 2005)。ビオトープとは特定の生物群集が形成さ れる条件を備えた最小単位の空間などとして定義される もので, 自然再生や生物多様性保全の手段としてしばし ば用いられている（篇佐ほか 2003 ; 高橋ほか 2009）. 国内では 2000 年代後半以降, 生物多様性保全を目的と して造成された湿地ビオトープに関する多くの事例が報 告されており, その内容は水田域に扔ける休耕地を湿地 ビオトープ化した事例（市川 2004 ; 北村 2008 ; 久米ほ か 2009; 大野・高橋 2009; 須田 2010; 高橋ほか 2010 ; 田中ほか 2013 ; 阪田・難波 2020), 非水田域に 湿地ビオトープを造成した事例（竹内ほか 2009 ; 山下 ほか 2009; 井上ほか 2013), また河川を中心とした湿 地ビオトープを造成した事例（松井・増田 2018）や, 流域生態系の一部としての湿地ビオトープを造成した事 例（田和ほか 2019）など様々なものがある。上述した 湿地ビオトープ造成の目的はその多くが生物の生息場の
再生を目指したものであるが, 同時にこのような休耕地 や非農地の湿地ビオトープ化は, 生物多様性保全への効 果のみならず，治水や水質浄化などグリーンインフラと しても大きな多面的機能を有することが指摘されている (グリーンインフラ研究会 2020 ; 西廣ほか 2020). 現在 国内では水田耕作面積は減少し続けており, 同時に休耕 田も増加している（農林水産省 2019）。したがって，こ うした休耕田を湿地ビオトープとして活用することには 様々な利点があるものと考えられ，特に水田域の生物多 様性を保全する場として機能させるためには, 湿地ビオ トープの構造や水生生物の生態に関する知見を今後も各 地で集積していく必要があるものと考えられる。

以上の背景より, 本研究では休耕田に造成した湿地ビ オトープの水質環境と生物相の状況を 3 年間にわたり毎 月調査した結果を報告するとともに, 特に水生昆虫類を 中心とした水生生物の多様性保全に寄与するビオトープ の環境構造や管理手法について考察を行う.

\section{材料と方法}

\section{調查地}

調查地は福岡県福津市手光地区に造成した湿地ビオト ープ (通称 ; 手光ビオトープ) である (Fig. 1). 本ビオ トープは標高約 $25 \mathrm{~m}$, 最大幅が東西約 $60 \mathrm{~m}$, 南北約 $120 \mathrm{~m}$ で, 10 年以上にわたり休耕していた水田を 2011 年 2 月に掘削して造成したものである（中島ほか 2012 ; 福岡県宗像・遠賀保健福祉環境事務所 2019). 本 ビオトープの周辺は主に水田域を中心とした農地，森林， 住宅地からなり, 農業用ため池も多数存在する。 な抏, これらのため池群は多くの希少種の生息地となっている ことから, 当地域は「生物多様性の観点から重要度の高 い湿地」に扔いて「No.457 古賀市㧍よび福津市のため 池群」に選定されている（環境省 2014）.

掘削前の休耕田はセイタカアワダチソウ Solidago altis$\operatorname{sim} a$ 等の草本が繁茂するやや湿った荒地となっており, 小型重機により 2 つの池（上池, 下池）と 1 つの水田, 及びそれらを結ぶ水路を造成した，上池は隣接した三面 コンクリート護岸の小河川（手光今川水系）から取水す ることができ, 取水された水は上池内を通過して水路を 経て水田に流れ込み，水田から流出した水は再度小河川 に流水込む構造となっている。 下池は上池や水路とは直 接つながっておらず，独立した止水域である。少河川か らの取水は堰上げによって行うが，取水をしない場合で も東側の森林脇からの湧水や地下水位などの影響から, 

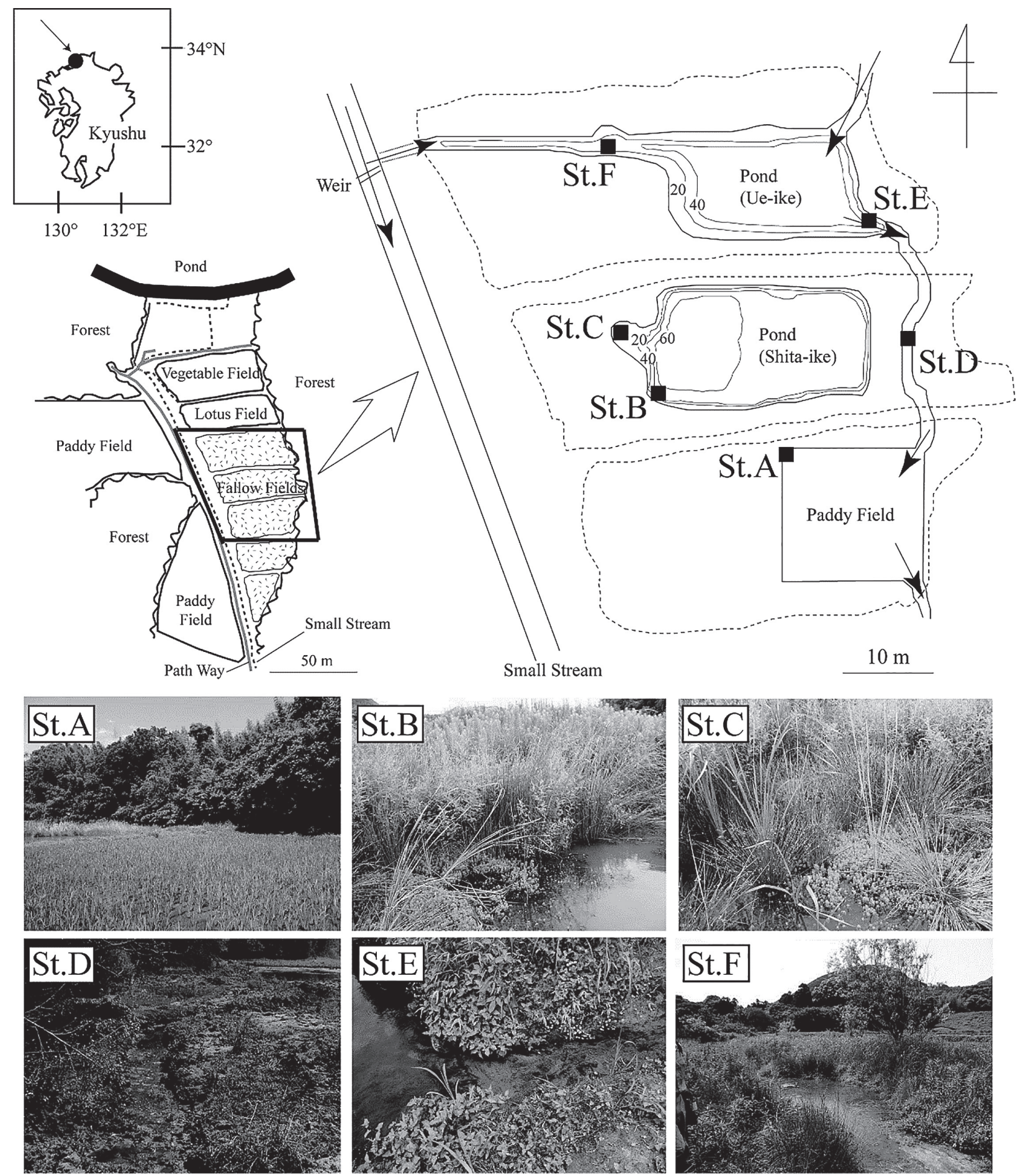

Fig. 1. Map of study area and location of the six survey stations. 調查地点の地図と 6 調査定点の位置.

上池, 下池，水路, 水田ともに完全に干上がることはほ とんどない.

本ビオトープ造成後調査を実施した 3 年間では, 下池 で夏季に数回の観察会を実施した際に陸域の草刈り, 水
田で稲の栽培・収穫を行ったが, その他の生物の持ち込 みは一切行わず，生物相の変化は自然の推移に任せた．

水生生物の採集と水質項目の測定

ビオトープ内に地点 $\mathrm{A} \sim \mathrm{F}$ の 6 定点を設けた（Fig. 1). 
地点 $\mathrm{A}$ は水田, 地点 $\mathrm{B}$ と $\mathrm{C}$ は下池, 地点 $\mathrm{D}$ は水路, 地 点 $\mathrm{E}$ と F は上池に位置する. 各定点は $1 \mathrm{~m}$ 四方とし, この各定点において 2011 年 4 月から 2014 年 3 月の 3 年 間, 毎月中旬に調査を行った。

採集調査は夕モ網（HOGA 社 IS40-1W；目合 $1 \mathrm{~mm}$, 幅 $40 \mathrm{~cm}$ ）を用い, 約 10 分間にわたって定点内を満遍 なくすくい採り採集を行った。採集した生物は目視で同 定できるものは種類と個体数を記録後, 生きたまま元の 場所に放流した。また，目視での同定ができない一部の 種については $70 \%$ エノール液において固定し研究室 に持ち帰り同定した。採集調査とあわせて, トンボ類 (成虫), アメンボ類 (成虫), 沈水植物を目視で記録し た. 水生昆虫類の種の同定 ·分類は基本的に川合 · 谷田 （2018）に従い,トンボ目については尾園ほか（2012） を, コウチュウ目とカメムシ目については中島ほか （2020）を参考にした. 沈水植物の基準 ・同定は角野 （2014）に従った.

水質項目の測定は毎回の採集調査の直前に行い, 6 定 点において水温, 電気伝導度 $(\mathrm{EC}), \mathrm{pH}$, 酸化還元電位 (ORP), 溶存酸素 (DO), 水深の 6 項目を測定・記録し た. 水深はプラスチック製定規を用いて各定点の中心を $1 \mathrm{~cm}$ 単位で計測した。 他の項目については多項目水質 計（HORIBA 社 U-50）を用いて計測した。また，本調 査地が農薬類に由来する有機污染物質の影響を受けてい るかどうかを確認するため, 547 種の農薬類が登録され た GC／MSデータベースを用いた土壤のスクリーニン グ分析（宮脇ほか 2013）を行った。分析には2011 年及 び 2013 年の 8 月に調查地点 A， B，Fでそれぞれ採取し た土壤を用いた。

以上の結果に基づてて水質環境の変化, 確認された水 生生物の種数・希少種数について整理を行った。希少種 は環境省（2020）及び福岡県（2014）において何らかの ランクに掲載されているものとした。 また, 水生昆虫類 を対象として月ごとの出現種数の変化, 地点ごとの種数 の変化, 多様度指数として Shannon-Wiener の H' (宮 下・野田 2003）の変化を調べた。さらに水面性を除く 真水生のカメムシ目・コウチュウ目を対象として, 周辺 のため池環境に生息する種組成との比較を行った。比較 対象としたため池は本ビオトープから北東約 $20 \mathrm{~m}$ に位 置する池 $\mathrm{A}$, 北西約 $2 \mathrm{~km}$ に位置する池 $\mathrm{B}$, 北約 $2 \mathrm{~km}$ に位置する池 C とし，2008 年～2014 年にかけて実施し た任意採集による調査結果を用いた。真水生種の定義は 中島ほか（2020）に従った。加えて, 侵略的な外来種の 出現状況, 沈水植物の出現状況を整理した.

\section{結 果}

水質測定項目

四重極型 GC/MS を用いた 2 回の土壤分析の結果, いずれも有機塩素系農薬 (DDT 類, $\mathrm{HCH}$ 類等) をはじ め, 殺虫剤（フィプロニル等）や除草剤等（シマジン 等）を含む農薬類はすべて定量下限未満であり, 本ビオ トープの土壤がこれらの影響を受けていないことが明ら かとなった。次に，調査した 6 定点において計測した 6 項目の水質環境の変化を示す (Fig. 2). 環境の大きな変 化として，定点 B と C を含む下池は 2013 年の 4, 5, 6 月に水がなくなり干出・乾燥したが, 他の地点・時期に おいては水が完全になくなるということはなかった．水 温は最高 $38.2^{\circ} \mathrm{C}$ (地点 $\mathrm{A}, 2012$ 年 7 月), 最低 $6.7^{\circ} \mathrm{C}$ (地点 $\mathrm{E}, 2012$ 年 1 月）であり，おおむね 7 抒にに高 く 12〜2月に低いという明瞭な季節性がみられた (Fig. 2a)。電気伝導度, $\mathrm{pH}$, 溶存酸素は地点間・季節間 で大きな差はなかった（Fig. $2 \mathrm{~b}, \mathrm{c}, \mathrm{e})$ ，酸化還元電位は 冬季から春季に高く，夏季に低いという季節性がみられ た（Fig. 2d）。水深は期間を通して全体として顕著に浅 くなっていく傾向がみられた（Fig. 2f).

\section{水生生物相}

全 36 回の定点による採集調査と全域の目視調査の結 果をあわせると, 両生類 7 種, 魚類 4 種, 水生昆虫類 69 種, 甲殼類 7 種, 貝類 6 種の合計 18 目 93 種の水生 動物を確認することができた（Table 1). 外来種はウシ ガエル Lithobates catesbeianus, アメリカザリガニ Procambarus clarkii, スクミリンゴガイ Pomacea canaliculata サカマキガイPhysa acutaの 4 種であった。沈水植物は イトトリゲモ Najas japonica, ミズオオバコOttelia alismoides, キクモ Limnophila sessiliflora, イトモ類の一種 Potamogedon sp.の 4 種が確認された。 確認された全て の水生動植物のうち, 環境省もしくは福岡県のレッドリ スト掲載種は 24 種であった。

定点調査において採集された水生昆虫類はカゲロウ目 (幼虫) 2 種, カワゲラ目 (幼虫) 1 種, トンボ目（幼 虫） 11 種, カメムシ目（成虫・幼虫） 14 種, コウチュ ウ目 (成虫・幼虫) 20 種, トビケラ目 (幼虫) 2 種, 八 エ目 (幼虫) 4 種であった。真水生種で幼虫も確認され たのはタイコウチ Laccotrephes japonensis, ハイイロチビ ミズムシ Micronecta sahlbergii, エサキコミズムシ Sigara septemlineata, オオミズムシ Hesperocorixa kolthoffi, マ ツモムシ Notonecta triguttata, コマツモムシ Anisops ogasawarensis, マルミズムシ Paraplea japonica, マメゲンゴ 

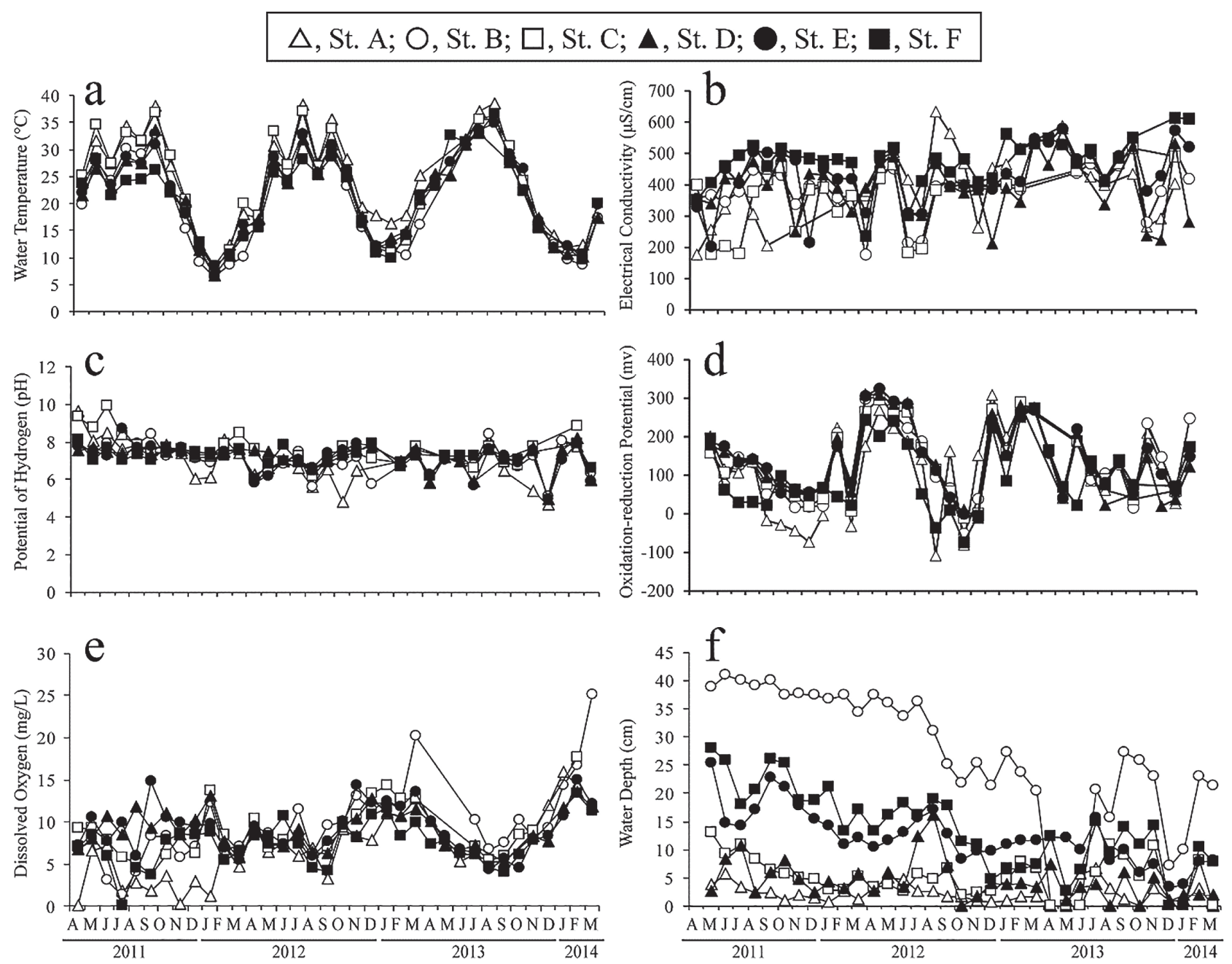

Fig. 2. Monthly changes of each water environments in six survey stations since April 2011 to March 2014. a, water temperature $\left({ }^{\circ} \mathrm{C}\right)$; b, electric conductivity $(\mu \mathrm{S} / \mathrm{cm})$; c, potential hydrogen $(\mathrm{pH})$; d, oxidation-reduction potential (mv); e, dissolved oxygen $(\mathrm{mg} / \mathrm{L}) ; \mathrm{f}$, water depth $(\mathrm{cm})$.

2011 年 4 月から 2014 年 3 月にかけての水質環境の毎月の変化. a, 水温; b, 電気伝導度 ; $\mathrm{c}, \mathrm{pH} ; \mathrm{d}$, 酸化還元 電位; e, 溶存酸素; f, 水深.

ロウ Agabus japonicus, ハイイロゲンゴロウ Eretes griseus, コガタノゲンゴロウ Cybister tripunctatus lateralis, ヒメガムシ Sternolophus rufipes であった。このうち, 真 水生種においては八イイロチビミズムシ，エサキコミズ ムシ，マメゲンゴロウの 3 種がほぼ全期間を通じて確認 された一方で，ホッケミズムシ Hesperocorixa distanti hokkensis, ホソマルチビゲンゴロウ Leiodytes miyamotoi, カンムリセスジゲンゴロウCopelatus kammuriensis, ミ ヤタケダルマガムシ Hydraena miyatakei, ゴマフガムシ Berosus punctipennis, キベリヒラタガムシ Enochrus japonicusの 6 種は各 1 回, 1 個体しか採集されなかった. 水生昆虫類の確認種数には明瞭な季節性があり，15 種 以上が確認された月は 1 年目が $7 \sim 12$ 月， 2 年目が 3 月
及び $5 \sim 10$ 月， 3 年目が $7 \sim 9$ 月で，いずれも 8 月を中 心とした夏季に種数が多く，その一方で確認された種数 が 10 種未満であったのは 1 年目が 1 月と 2 月, 2 年目 が $12 \sim 2$ 月， 3 年目が 4 月及び $11 \sim 3$ 月で，いずれも 2 月を中心とした冬季に種数が少なかった（Table 2 , Fig. 3). 3 年間の月別の平均種数 $\pm \mathrm{SD}$ は 1 月が $6.0 \pm$ $0.0,2$ 月が $4.0 \pm 1.0,3$ 月が $10.7 \pm 4.9,4$ 月が $10.7 \pm$ $2.5,5$ 月が $13.0 \pm 6.1 ， 6$ 月が $15.0 \pm 6.2,7$ 月が 15.0 $\pm 6.2,8$ 月 が $21.3 \pm 1.2,9$ 月が $17.0 \pm 1.7,10$ 月 が $15.0 \pm 1.0,11$ 月が $12.0 \pm 5.6,12$ 月が $8.3 \pm 6.8$ であり， 8 月にもっとも多く，2月にもっとも少なかった．

調査地点別の水生昆虫類の種数は地点 $\mathrm{B}$ が多く, 地 点 D が少ない傾向がみられた（Fig. 4a）。全期間を通じ 
Table 1. All aquatic animals and submerged pltants by our survey from April 2011 to March 2014.

2011 年 4 月から 2014 年 3 月に実施した調査で確認されたすべての水生動物及び沈水植物.

\begin{tabular}{|c|c|}
\hline \multicolumn{2}{|l|}{ Amphibia } \\
\hline Caudata & Hynobius nebulosus*, Cynops pyrrhogaster ${ }^{*}$ \\
\hline Anura & Hyla japonica, Rana japonica*, Lithobates catesbeianus**, Glandirana rugosa*, Fejervarya kawamurai \\
\hline \multicolumn{2}{|l|}{ Osteichthyes } \\
\hline Cypriniformes & Carassius langsdorfii, Misgurnus anguillicaudatus* \\
\hline Perciformes & Rhinogobius similis, $R$. sp. OR \\
\hline \multicolumn{2}{|l|}{ Insecta } \\
\hline Ephemeroptera & Cloeon sp., Caenis sp. \\
\hline Plecoptera & Nemoura sp. \\
\hline Odonata & $\begin{array}{l}\text { Sympecma paedisca*, Lestes sponsa, Copera annulata, Ceriagrion melanurum*, C. nipponicum*, } \\
\text { Paracercion calamorum, Ischnura senegalensis, Anaciaeschna martini, Anax parthenope, Trigomphus } \\
\text { interruptus*, Epophthalmia elegans, Rhyothemis fuliginosa, Sympetrum eroticum, S. kunckeli, Pseudo- } \\
\text { themis zonata, Crocothemis servilia, Pantala flavescens, Lyriothemis pachygastra, Orthetrum albisty- } \\
\text { lum, O. japonicum, O. melania }\end{array}$ \\
\hline Hemiptera & $\begin{array}{l}\text { Laccotrephes japonensis, Ranatra chinensis*, } R \text {. unicolor, Micronecta sahlbergii, Hesperocorixa distanti } \\
\text { hokkensis*, H. kolthoffi*, H. mandshurica*, Sigara septemlineata, S. bellula*, Notonecta triguttata, } \\
\text { Anisops ogasawarensis, A. exuguus, Paraplea japonica, P. indistinguenda, Hydrometra procera, } \\
\text { Microvelia douglasi, M. horvathi, Aquarius paludum paludum, Gerris latiabdominis }\end{array}$ \\
\hline Coleoptera & $\begin{array}{l}\text { Peltodytes intermedius, Noterus japonicus, Hydrovatus acuminatus*, Hydroglyphus japonicus, } \\
\text { Leiodytes miyamotoi*, Copelatus kammuriensis*, Agabus japonicus, Rhantus suturalis, Eretes griseus, } \\
\text { Hydaticus rhantoides*, Cybister tripunctatus lateralis*, Hydraena miyatakei, Berosus punctipennis, B. } \\
\text { lewisius, Sternolophus rufipes, Enochrus japonicus, E. simulans, Helochares pallens, H. nipponicus*, } \\
\text { Luciola lateralis* }^{*}\end{array}$ \\
\hline Trichoptera & Cheumatopsyche sp., Lepidostoma sp. \\
\hline Diptera & Tipulidae sp., Chironomus sp., Stratiomys japonica, Eristalis sp. \\
\hline \multicolumn{2}{|l|}{ Malacostraca } \\
\hline Decapoda & $\begin{array}{l}\text { Caridina typus, Neocaridina denticulata, Palaemon paucidens, Procambarus clarkii**, Eriocheir } \\
\text { japonica }\end{array}$ \\
\hline Isopoda & Asellus hilgendorfi \\
\hline Amphipoda & Gammarus sp. \\
\hline \multicolumn{2}{|l|}{ Gastropoda } \\
\hline Architaenioglossa & Cipangopaludina chinensis laeta*, Bellamya quadrata histrica, Pomacea canaliculata** \\
\hline Sorbeoconcha & Semisulcospira libertina \\
\hline Pulmonata & Physa acuta* ${ }^{* *}$ \\
\hline Hygrophila & Planorbidae sp. \\
\hline Submerged plants & Najas japonica*, Ottelia alismoides*, Potamogeton sp., Limnophila sessiliflora \\
\hline
\end{tabular}

*, Threatened Species by Ministory of Environment (2020) and Fukuoka Prefecture (2014); **, alien species

た各地点の平均種数 $\pm \mathrm{SD}$ は地点 $\mathrm{A}$ が $3.0 \pm 2.5$, 地点 $\mathrm{B}$ が $7.5 \pm 5.4$, 地点 C が $3.9 \pm 3.2$, 地点 $\mathrm{D}$ が $1.0 \pm 1.2$, 地点 $\mathrm{E} か ゙ 4.0 \pm 2.6$, 地点 $\mathrm{F} か ゙ 3.4 \pm 2.3$ であった。また, 調查地点別の水生昆虫類の多様度指数 $H^{\prime}$ は地点 $\mathrm{B}$ が高 く, 地点 D が低い傾向がみられた（Fig. 4b）。全期間を 通じた各地点の多様度指数 $H^{\prime}$ の平均值 $\pm \mathrm{SD}$ は地点 $\mathrm{A}$ が $1.3 \pm 0.8$, 地点 B が $2.2 \pm 1.0$, 地点 C が $1.5 \pm 0.9$, 地点 $\mathrm{D}$ が $0.6 \pm 0.7$, 地点 $\mathrm{E}$ が $1.4 \pm 0.8$, 地点 $\mathrm{F}$ が 1.5

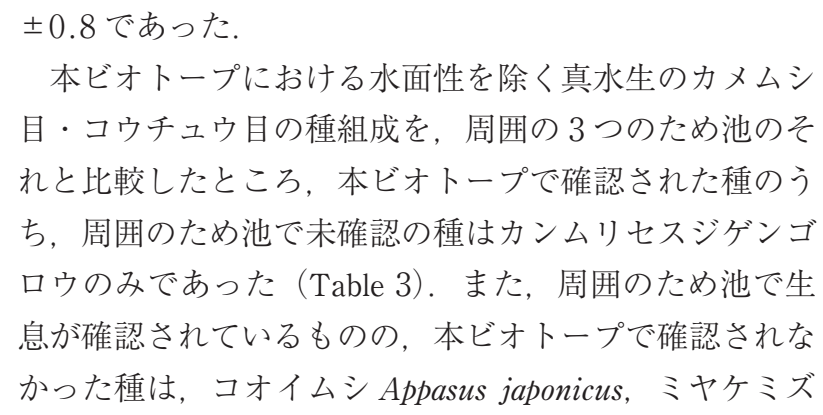
目・コウチュウ目の種組成を, 周囲の 3 つのため池のそ れと比較したところ, 本ビオトープで確認された種のう ち, 周囲のため池で未確認の種はカンムリセスジゲンゴ ロウのみであった（Table 3)。 また, 周囲のため池で生 息が確認されているものの, 本ビオトープで確認されな かった種は, コオイムシ Appasus japonicus, ミヤケミズ 
Table 2. List of aquatic insects collected by our survey at six stations.

6 調査定点によって採集された水生昆虫類のリスト.

\begin{tabular}{|c|c|c|c|c|c|c|}
\hline \multirow{2}{*}{ Scientific Name } & \multirow{2}{*}{ Stage } & \multirow{2}{*}{ Japanese Name } & 2011 & 2012 & 2013 & \multirow{2}{*}{$\begin{array}{c}2014 \\
\text { J F M }\end{array}$} \\
\hline & & & $\overline{\mathrm{A} \mathrm{M} \mathrm{J} \mathrm{J} \mathrm{A} \mathrm{S} \mathrm{O} \mathrm{N} \mathrm{D}}$ & J F M A M J J A S O N D & J F M A M J JASOND & \\
\hline \multicolumn{7}{|l|}{ Hemiptera } \\
\hline Laccotrephes japonensis & A\&L & Taikouchi & - - - ०००-० - & 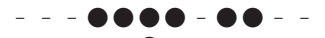 & 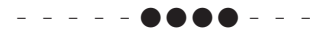 & --- \\
\hline Ranatra chinensis & A & Mizukamakiri & $-\cdots-\cdots$ & $\ldots-\cdots-\cdots$ & $\ldots-\ldots \ldots$ & - - - \\
\hline Ranatra unicolor & A & Hime-mizukamakiri & $\ldots \ldots$ & $---\bullet-\bullet \bullet-\bullet--$ & $\ldots \ldots \ldots$ & - - \\
\hline Micronecta sahlbergii & A\&L & Haiiro-chibimizumushi & 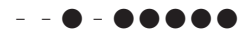 & 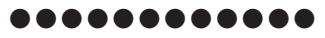 & 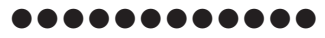 & $\bullet \bullet \bullet$ \\
\hline Hesperocorixa distanti hokkensis & A & Hokke-mizumushi & $-\cdots$ & & $0 \ldots-\ldots \ldots$ & - - \\
\hline Hesperocorixa kolthoffi & A\&L & Oo-mizumushi & $--\bullet-\bullet--\bullet$ & $\ldots-\ldots \ldots$ & $----\boldsymbol{\bullet}-\cdots-$ & - - \\
\hline Hesperocorixa mandshurica & A & Naga-mizumushi & $\ldots-\cdots$ & $\ldots \ldots \ldots$ & $\ldots \ldots-\cdots-$ & 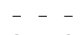 \\
\hline Sigara septemlineata & $A \& L$ & Esaki-komizumushi & $-0-$ & $\bullet \bullet \bullet-$ & 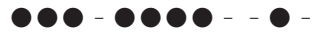 & - - \\
\hline Sigara bellula & A & Omonaga-komizumushi & & & & \\
\hline Notonecta triguttata & A\&L & Matsumomushi & - - - & & 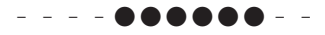 & 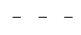 \\
\hline Anisops ogasawarensis & A\&L & Komatsumomushi & 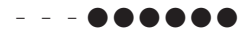 & 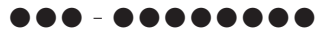 & 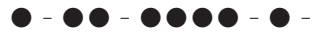 & - - \\
\hline Anisops exuguus & A & Chibi-komatsumomushi & $\ldots \ldots-\ldots$ & 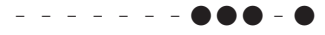 & $\ldots \ldots \ldots$ & - - - \\
\hline Paraplea japonica & A\&L & Marumizumushi & - - -๑९९९ - - & $---\bullet$ & 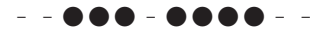 & 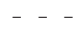 \\
\hline Paraplea indistinguenda & A & Hime-marumizumushi & $-\cdots-\cdots$ & $-\cdots$ & $\ldots \ldots-\cdots$ & -- \\
\hline \multicolumn{7}{|l|}{ Coleoptera } \\
\hline Peltodytes intermedius & A & Kogashira-mizumushi & ----0 & --- & $-\ldots-\cdots$ & --- \\
\hline Noterus japonicus & A & Kotsubu-gengorou & $\bullet \bullet \bullet$ & $0000--$ & - - - - - - ๑० - - & $-\cdots$ \\
\hline Hydrovatus acuminatus & A & Ko-marukeshi-gengorou & & $-\ldots$ & $\cdots--\bullet-\bullet \bullet-\cdots$ & - - \\
\hline Hydroglyphus japonicus & A & Chibi-gengorou & $-\bullet--\bullet-\bullet$ & $---\bullet$ & $-----\bullet--\bullet_{-}^{-}$ & - - \\
\hline Leiodytes miyamotoi & A & Hoso-maruchibi-gengorou & $\ldots-\ldots$ & $-\ldots-$ & $\ldots-\cdots-\cdots$ & - - \\
\hline Copelatus kammuriensis & A & Kanmuri-sesuji-gengorou & $\ldots \ldots \ldots$ & $\ldots \ldots \ldots$ & $\ldots \ldots-\ldots$ & - - \\
\hline Agabus japonicus & $A \& L$ & Mame-gengorou & $\bullet \bullet \bullet \bullet---\bullet 0$ & 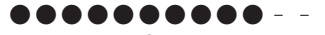 & 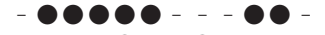 & - - \\
\hline Rhantus suturalis & A & Hime-gengorou & $---00^{-}$ & $-\cdots-$ & $\cdots--\bullet-\bullet-\cdots$ & -- \\
\hline Eretes griseus & A\&L & Haiiro-gengorou & 0 - - & 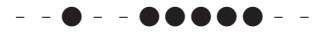 & 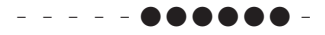 & - - - \\
\hline Hydaticus rhantoides & A & Usuiro-shima-gengorou & $0-\cdots--$ & $\ldots-\cdots-\ldots$ & 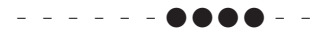 & - - \\
\hline Cybister tripunctatus lateralis & A\&L & Kogatano-gengorou & $\ldots \ldots-\ldots$ & $\ldots \ldots \ldots$ & $\cdots-\cdots-\bullet-\cdots$ & - - \\
\hline Hydraena miyatakei & A & Miyatake-darumagamushi & $\ldots \ldots \ldots$ & $\ldots \ldots \ldots$ & $-\cdots-\cdots--$ & - - - \\
\hline Berosus punctipennis & A & Gomafu-gamushi & $0 \ldots \ldots$ & $\ldots \ldots \ldots$ & $\ldots-\ldots-\ldots$ & - - - \\
\hline Berosus lewisius & A & Togeba-gomafu-gamushi & - - ○૦- - - - & $\ldots \ldots \ldots$ & $\ldots \ldots-\ldots$ & - - \\
\hline Sternolophus rufipes & $A \& L$ & Hime-gamushi & 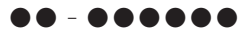 & 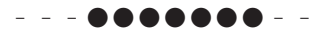 & 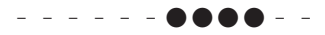 & - - \\
\hline Enochrus japonicus & A & Kiberi-hirata-gamushi & 0 - . . - - & $\ldots \ldots \ldots$ & $\ldots-\ldots-\ldots$ & - - - \\
\hline Enochrus simulans & A & Kïro-hirata-gamushi & $\bullet \bullet \bullet-\bullet$ & $-\bullet \bullet--$ & $---\bullet--\bullet \bullet-\bullet--$ & - - \\
\hline Helochares pallens & A & Ruisu-hirata-gamushi & $---\bullet-$ & $-\ldots-0$ & $----\bullet \bullet--\bullet--$ & - - \\
\hline Helochares nipponicus & A & Suji-hirata-gamushi & 00000 & 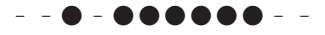 & $---\bullet-\bullet \bullet--\bullet--$ & - - \\
\hline Luciola lateralis & $\mathrm{L}$ & Heike-botaru & $-\ldots-\ldots-$ & $\ldots-\cdots-\cdots$ & $\ldots--\boldsymbol{0}_{-}-\cdots$ & -- \\
\hline \multicolumn{7}{|l|}{ Ephemeroptera } \\
\hline Cloeon sp. & $\mathrm{L}$ & Futaba-kagerou-zoku & $\ldots-$ & $--\bullet-$ & $--0--$ & - - \\
\hline Caenis sp. & $\mathrm{L}$ & Himeshiro-kagerou-zoku & $\ldots-\cdots$ & $\ldots-\cdots$ & $\ldots \ldots \ldots$ & - - - \\
\hline \multicolumn{7}{|l|}{ Plecoptera } \\
\hline Nemoura sp. & $\mathrm{L}$ & Onashi-kawagera-zoku & $\cdots-\cdots-\cdots$ & $\cdots-\cdots-\cdots$ & $\ldots-\cdots-\cdots-\cdots$ & --- \\
\hline \multicolumn{7}{|l|}{ Odonata } \\
\hline Copera annulata & $\mathrm{L}$ & Monosashi-tonbo & $-\ldots-\ldots$ & $\ldots-\cdots \cdots$ & $---\ldots-\cdots$ & - - - \\
\hline Coenagrionidae spp. & $\mathrm{L}$ & It & $--00---00$ & 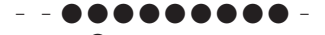 & 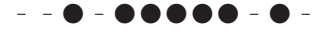 & - - - \\
\hline Anaciaeschna martini & $\mathrm{L}$ & Marutan-yanma & $\ldots \ldots$ & ---0 & $\ldots-\cdots-\ldots$ & - - \\
\hline Anax sp. & $\mathrm{L}$ & Gin-yanma-zoku & $\bullet \bullet--\bullet$ & $--0--0$ & - - - - ๑ - ๑०० - & - - \\
\hline Trigomphus interruptus & $\mathrm{L}$ & Futasuji-sanae & $-\cdots-\bullet$ & $----\bullet-$ & - - ๑ - - - - - & - - - \\
\hline Epophthalmia elegans & $\mathrm{L}$ & Oo-yama-tonbo & $\ldots-\ldots-\cdots$ & $\ldots \ldots \ldots$ & $\ldots-\cdots-\cdots$ & - - \\
\hline Rhyothemis fuliginosa & $\mathrm{L}$ & Chou-tonbo & $\ldots \ldots \ldots$ & $\ldots-\cdots, \cdots$ & $\ldots \ldots-\cdots$ & - - \\
\hline Crocothemis servilia & $\mathrm{L}$ & Syoujyou-tonbo & $-\ldots--\boldsymbol{O}_{-}$ & $\ldots \ldots-\ldots$ & $-\ldots-\ldots-\ldots \bullet \bullet-$ & 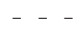 \\
\hline Lyriothemis pachygastra & $\mathrm{L}$ & Harabiro-tonbo & $\ldots \ldots \ldots$ & $\ldots-\bullet \bullet \ldots$ & $\ldots \ldots \ldots$ & -- \\
\hline Orthetrum spp. & $\mathrm{L}$ & Shiokara-tonbo-zoku & 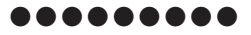 & & & $\bullet \bullet \bullet$ \\
\hline Libellulidae spp. & $\mathrm{L}$ & Tonbo-ka & $-\cdots-$ & & - - - - - ๑๑ - - - & \\
\hline \multicolumn{7}{|l|}{ Trichoptera } \\
\hline Cheumatopsyche sp. & $\mathrm{L}$ & Shima-tobikera-zoku & $\ldots \ldots$ & $\ldots \ldots$ & $\ldots \ldots$ & - - \\
\hline Lepidostoma sp. & $\mathrm{L}$ & Kakutsutsu-tobikera-zoku & $-\cdots$ & -- & $\ldots-\cdots$ & - - - \\
\hline \multicolumn{7}{|l|}{ Diptera } \\
\hline Tipulidae sp. & $\mathrm{L}$ & Gaganbo-ka & $\ldots \ldots \ldots$ & $\ldots \ldots \ldots$ & $\ldots-\cdots \cdots$ & - - \\
\hline Chironomus sp. & $\mathrm{L}$ & Yusurika-zoku & ๑०००००००० & & & $\bullet \bullet \bullet$ \\
\hline Stratiomys japonica & $\mathrm{L}$ & Mizu-abu & & & & \\
\hline Eristalis sp. & $\mathrm{L}$ & Hana-abu-zoku & $\ldots-\cdots$, & $\ldots-\cdots \cdots$ & $\mathbf{0}-\mathbf{0} \cdots \cdots$ & $-0-$ \\
\hline & Total s & ecies number & 131011172317171816 & 76151420232123231877 & 75149111419211719144 & 746 \\
\hline
\end{tabular}

A, adult; L, larva 


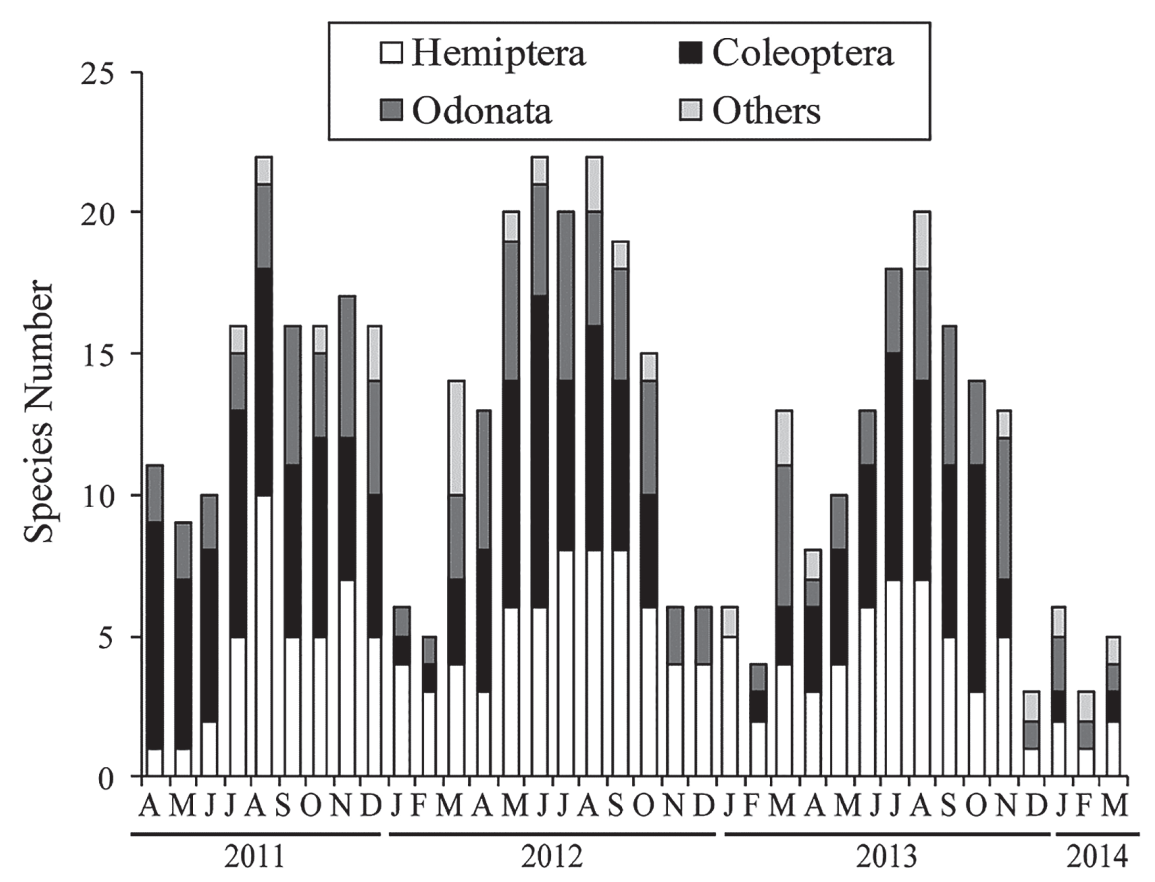

Fig. 3. Monthly change of species number of aquatic insects since April 2011 to March 2014. 2011 年 4 月から 2014 年 3 月にかけての水生昆虫（カメムシ目, コウチュウ目, トンボ目，その他）の種数の毎月の変化.

ムシ Xenocorixa vittipennis, コバンムシ Ilyocoris cimicoides exclamationis, クビボソコガシラミズムシ Haliplus japonicus, キイロコガシラミズムシ Haliplus eximius, ヒ メコガシラミズムシ Haliplus ovalis, ツブゲンゴロウ Laccophilus difficilis, ルイスツブゲンゴロウ Laccophilus lewisius, チャイロマメゲンゴロウ Agabus browni, タマ ガムシ Amphiops mater, マメガムシ Regimbartia attenuata，コガムシ Hydrochara affinisの 12 種であった.

確認された外来種 4 種のうち, 生態系被害防止外来種 リスト（環境省 2015）に掲載されている侵略性のある 外来種としては, ウシガエル, アメリカザリガニ, スク ミリンゴガイの 3 種が確認された。いずれの種も本ビオ トープが掘削された 2011 年の 8 月以降から確認され始 めた（Fig. 5)。スクミリンゴガイは 2011 年, 2012 年, 2013 年ともに 8 月前後には多くの個体が確認されたが, 冬季には生きた個体がほとんどみられなかった。アメリ カザリガニは 2011 年の採集個体数は少なかったが, 2012 年, 2013 年の 8 月前後には多数の個体が確認され た. ウシガエルは調查期間を通じて確認された個体数は 少なかったが, 2013 年 9 月のみ幼生（オタマジャクシ） がまとまって採集された。

沈水植物は前述した 4 種が確認されたが，4 種ともに 確認されたのは本ビオトープが掘削された 2011 年の 7
〜11月にかけてのみで（Fig. 6）, この時には下池全体 にこれら 4 種の沈水植物と抽水植物のコナギ Monochoria vaginalis，イボクサ Murdannia keisak 等からなる群落が 形成された（Fig. 7a）。しかし 2012 年はキクモ 1 種のみ が岸際のみで確認され，群落も形成されなかった (Fig. 7b)。その後 2013 年の $7 \sim 8$ 月にキクモが下池全 体に群落を形成したが，9月には消滅した。また同じ 2013 年 9 月には水田でミズオオバコが 1 株確認された が, 10 月には消滅した。

\section{考 察}

水質測定項目のうち, $\mathrm{pH}$ ，溶存酸素の 2 つは，特に 水生生物の生息に影響を与える項目である。一般的に国 内の自然環境（湖沼; 農業用水の場合）に扔けるこれら 2 項目の参考値として, $\mathrm{pH}$ は 6.5 8.5, 溶存酸素は湖 沼に扔いて $5 \mathrm{mg} / \mathrm{L}$ 以上の值をとることが知られてい る（環境省 2019）。本調査ではこれらの参考値を上回る， あるいは下回る場合もあったが，お拉むねこれらの参考 值内で数值は安定していたととらえることができる。ま た, 農薬類が土壤や農地の生物に負の影響を与えること については多くの研究例があるが（例えば, Jänsch et al. 2006 ; Kasai et al. 2016 ; Nakanishi et al. 2018 ; Ito et 

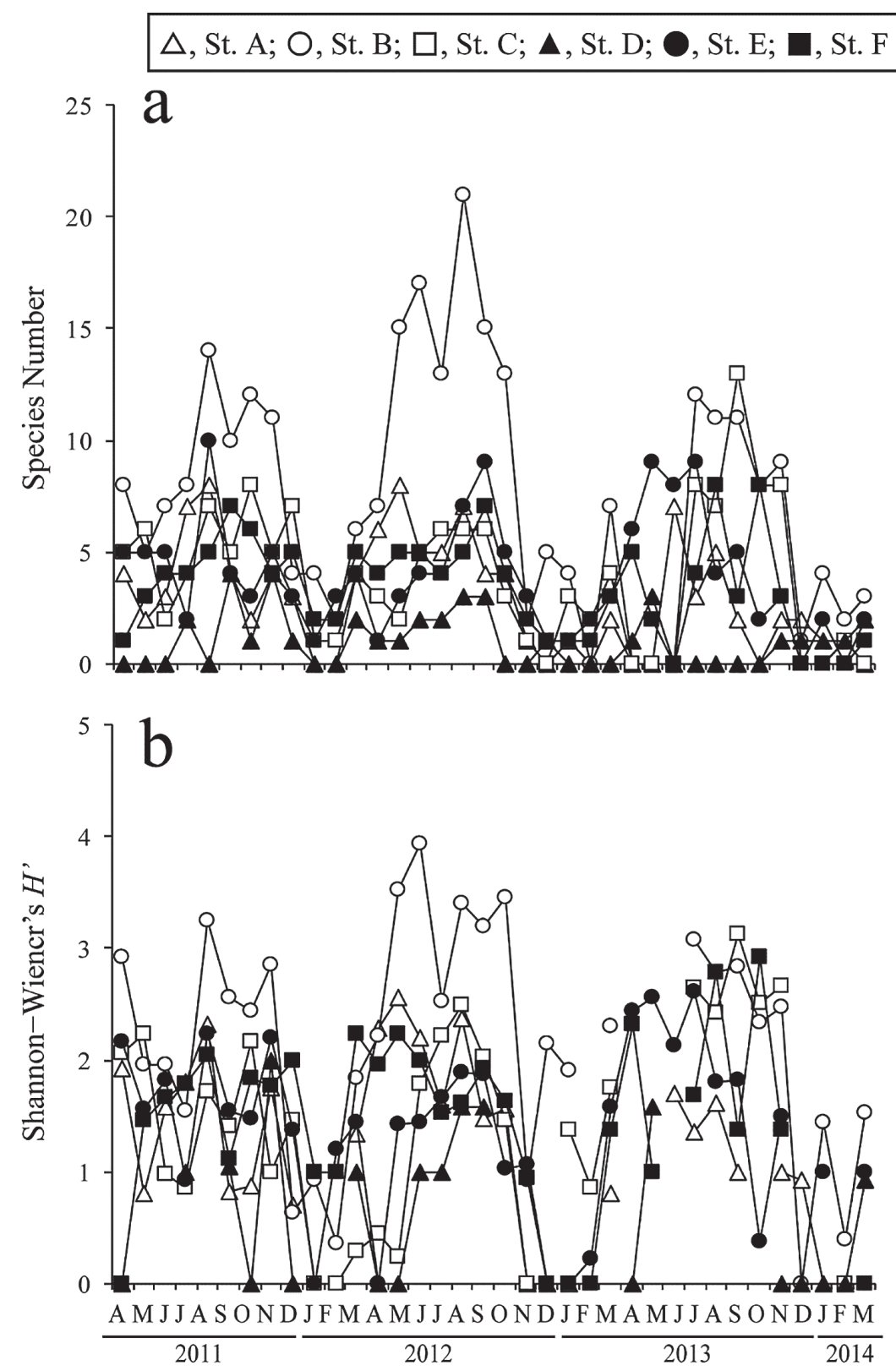

Fig. 4. Monthly changes of species number (a) and Shanon-Wiener's $H^{\prime}$ (b) of aquatic insects in six survey stations since April 2011 to March 2014.

2011 年 4 月から 2014 年 3 月にかけての各地点に扔ける水生昆虫の種数と多様 度指数 $\left(H^{\prime}\right)$ の毎月の変化.

al. 2020), 本研究では底泥を対象に網羅的な分析を行い, そうした農薬類が検出されないことを明らかにした。こ れらのことから，本ビオトープは生物に悪影響を与える ような水質環境を有した場所ではないことが明らかであ る.したがって, その生物相の変遷の結果は, 構造的な 物理環境の変化, 自然の生物の移出入, 外来種等の影響 によって生じたものとして以下の考察を行う.
生物多様性保全の観点からの本ビオトープの効果

本調査では 3 年間で 22 種の希少種を含む 93 種の水生 動物, 2 種の希少種を含む 4 種の沈水性植物が確認され た. 水生動物のうち, 特に水生のカメムシ目とコウチュ ウ目は環境保全型農業の取り組み評価のための指標生物 として適していることが知られている（農林水産省農林 水産技術会議事務局 2012)。この点から特に真水生種の 
Table 3. List of true aquatic Hemiptera and Coleoptera at Tebika Biotope, Pond A, Pond B, and Pond C. 手光ビオトープ及び池 $\mathrm{A}$ ，池 $\mathrm{B}$ ，池 Cに扔ける真水生のカメムシ目とコウチュウ目のリスト.

\begin{tabular}{|c|c|c|c|c|c|}
\hline Scientific Name & Japanese Name & Tebika Biotope & Pond A & Pond B & Pond $\mathrm{C}$ \\
\hline \multicolumn{6}{|l|}{ HEMIPTERA } \\
\hline 1 Laccotrephes japonensis & Taikouchi & 0 & 0 & 0 & \\
\hline 2 Ranatra chinensis & Mizukamakiri & & & 0 & \\
\hline 3 Ranatra unicolor & Hime-mizukamakiri & O & & 0 & 0 \\
\hline 4 Appasus japonicus & Kooimushi & & & & \\
\hline 5 Micronecta sahlbergii & Haiiro-chibimizumushi & 0 & 0 & ? & \\
\hline 6 Hesperocorixa distanti hokkensis & Hokke-mizumushi & & & & 0 \\
\hline 7 Hesperocorixa kolthoffi & Oo-mizumushi & & 0 & & O \\
\hline 8 Hesperocorixa mandshurica & Naga-mizumushi & & & & 0 \\
\hline 9 Xenocorixa vittipennis & Miyake-mizumushi & & & & 0 \\
\hline 10 Sigara septemlineata & Esaki-komizumushi & & & & \\
\hline 11 Sigara bellula & Omonaga-komizumushi & & & & O \\
\hline 12 Ilyocoris cimicoides exclamationis & Koban-mushi & & & & \\
\hline 13 Notonecta triguttata & Matsumomushi & 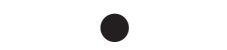 & & & O \\
\hline 14 Anisops ogasawarensis & Komatsumomushi & & & & \\
\hline 15 Anisops exuguus & Chibi-komatsumomushi & & & & \\
\hline 16 Paraplea japonica & Marumizumushi & & & 0 & O \\
\hline 17 Paraplea indistinguenda & Hime-marumizumushi & & ? & & \\
\hline \multicolumn{6}{|l|}{ COLEOPTERA } \\
\hline 1 Peltodytes intermedius & Kogashira-mizumushi & ○ & 0 & 0 & O \\
\hline 2 Haliplus japonicus & Kubiboso-kogashira-mizumushi & & & & \\
\hline 3 Haliplus eximius & Kiiro-kogashira-mizumushi & & & & \\
\hline 4 Haliplus ovalis & Hime-kogashira-mizumushi & & & & \\
\hline 5 Noterus japonicus & Kotsubu-gengorou & 0 & & 0 & 0 \\
\hline 6 Hydrovatus acuminatus & Ko-marukeshi-gengorou & & C & & \\
\hline 7 Hydroglyphus japonicus & Chibi-gengorou & & & 0 & 0 \\
\hline 8 Leiodytes miyamotoi & Hoso-maruchibi-gengorou & 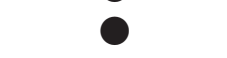 & & & \\
\hline 9 Laccophilus difficilis & Tsubu-gengorou & & & & \\
\hline 10 Laccophilus lewisius & Ruisu-tsubu-gengorou & & & 0 & \\
\hline 11 Copelatus kammuriensis & Kanmuri-sesuji-gengorou & 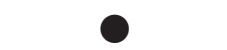 & & & \\
\hline 12 Agabus japonicus & Mame-gengorou & O & O & 0 & O \\
\hline 13 Agabus browni & Chairo-mame-gengorou & & & & \\
\hline 14 Rhantus suturalis & Hime-gengorou & 0 & & 0 & \\
\hline 15 Eretes griseus & Haiiro-gengorou & & & & 0 \\
\hline 16 Hydaticus rhantoides & Usuiro-shima-gengorou & 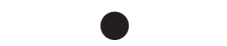 & & 0 & 0 \\
\hline 17 Hydaticus grammicus & Ko-shima-gengorou & & & & \\
\hline 18 Cybister tripunctatus lateralis & Kogatano-gengorou & 0 & O & 0 & 0 \\
\hline 19 Hydraena miyatakei & Miyatake-darumagamushi & 0 & O & & \\
\hline 20 Amphiops mater & Tama-gamushi & & & 0 & 0 \\
\hline 21 Berosus punctipennis & Gomafu-gamushi & 0 & O & & \\
\hline 22 Berosus lewisius & Togeba-gomafu-gamushi & 0 & & 0 & \\
\hline 23 Regimbartia attenuata & Mame-gamushi & & 0 & 0 & 0 \\
\hline 24 Hydrochara affinis & Ko-gamushi & & & 0 & \\
\hline 25 Sternolophus rufipes & Hime-gamushi & 0 & 0 & 0 & 0 \\
\hline 26 Enochrus japonicus & Kiberi-hirata-gamushi & 0 & 0 & & \\
\hline 27 Enochrus simulans & Kiiro-hirata-gamushi & 0 & 0 & 0 & 0 \\
\hline 28 Helochares pallens & Ruisu-hirata-gamushi & 0 & 0 & 0 & 0 \\
\hline 29 Helochares nipponicus & Suji-hirata-gamushi & 0 & 0 & 0 & 0 \\
\hline
\end{tabular}



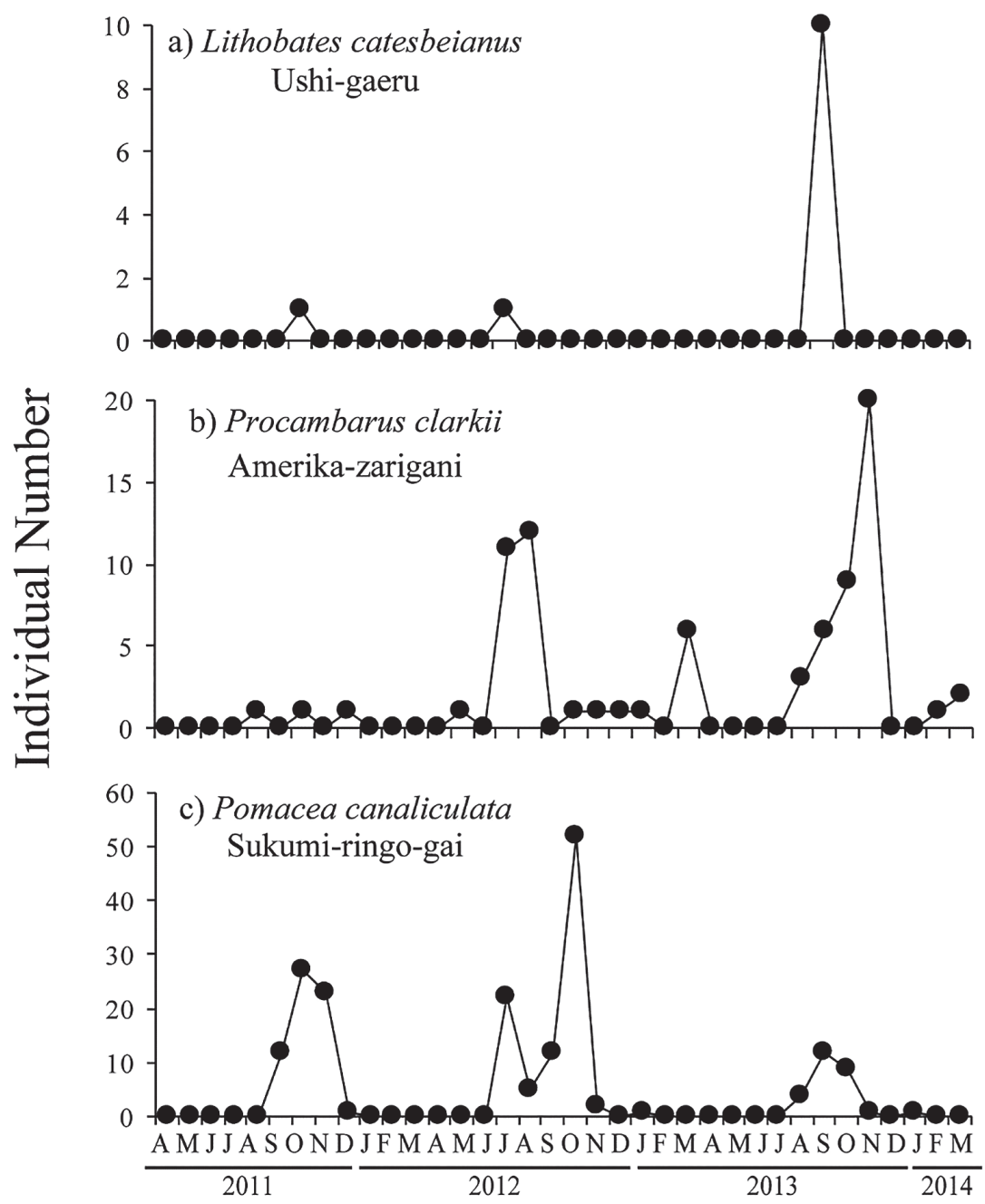

Fig. 5. Monthly changes of individual number of three alien species since April 2011 to March 2014. a, Lithobates catesbeianus; b, Procambarus clarkii; c, Pomacea canaliculata.

2011 年 4 月から 2014 年 3 月にかけての 3 種の外来種個体数の毎月の変化. a, ウシガエル ; b, アメリカザリガニ； c，スクミリンゴガイ

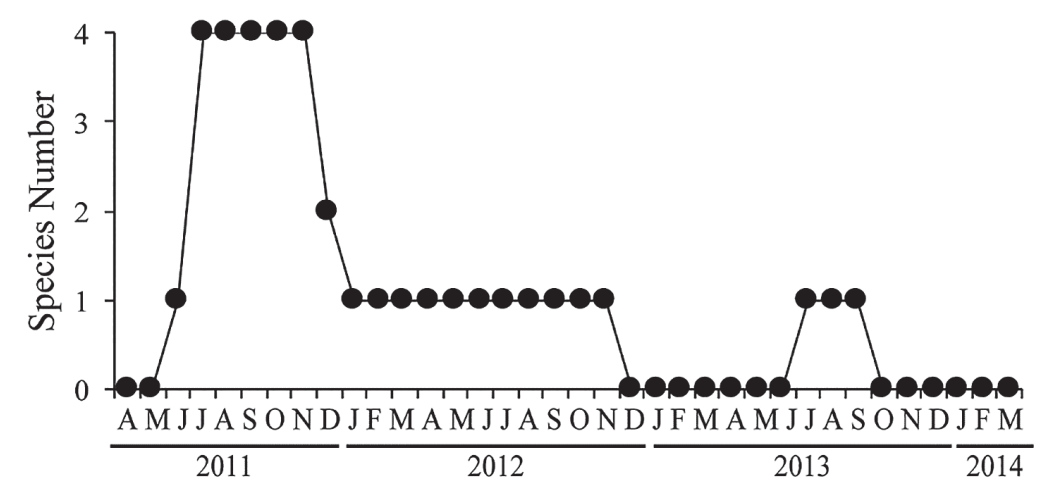

Fig. 6. Monthly change of species number of submerged plants since April 2011 to March 2014. 2011 年 4 月から 2014 年 3 月にかけての沈水植物種数の毎月の変化. 

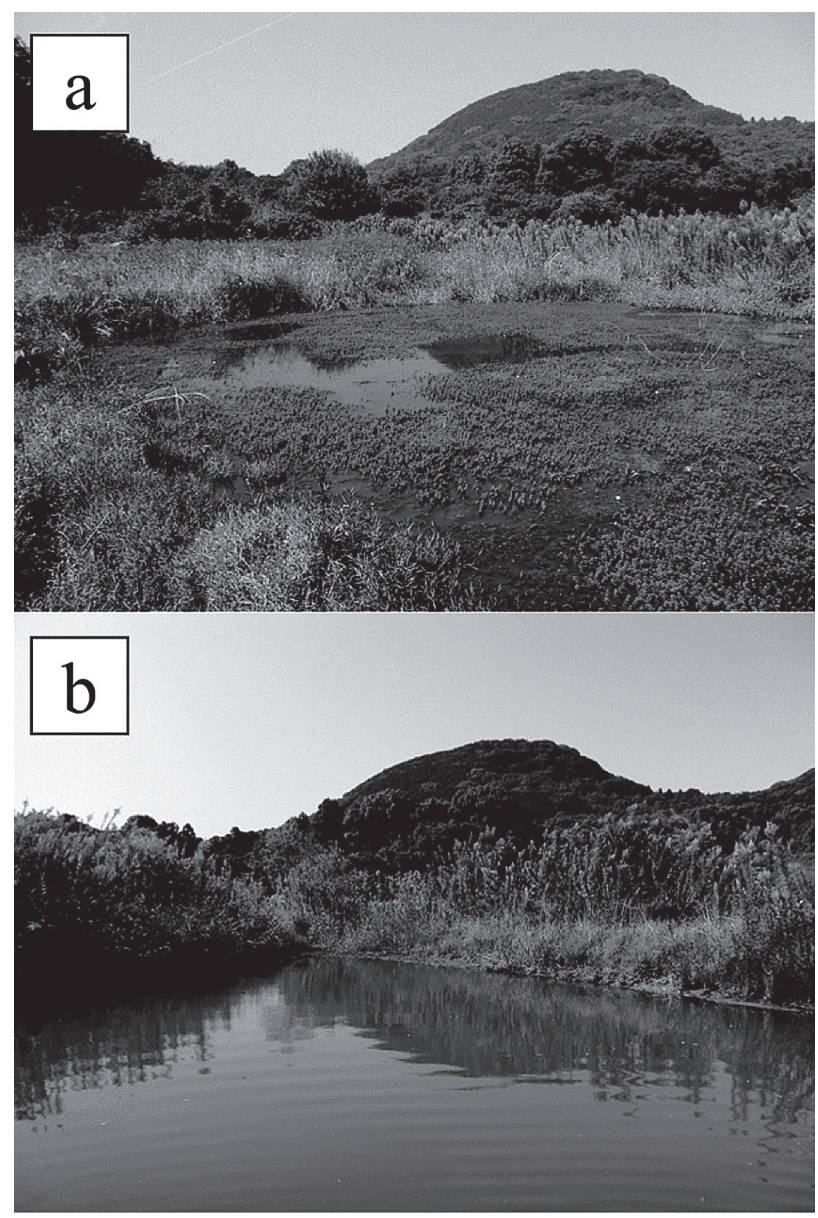

Fig. 7. Change of aquatic plant community at Shimo-ike in Tebika Biotope. a, 13. October 2011; b, 15. October 2012.

手光ビオトープ下池に打ける水草群落の変化. a, 2011 年 10 月 13 日； b , 2012 年 10 月 15 日.

種数に注目して, 既知の同様の研究結果と比較を行うと, 茨城県では造成後 6 年でカメムシ目が 9 種, コウチュウ 目が 14 種（田中ほか 2013），奈良県では造成後 1 年で カメムシ目が 6 種，コウチュウ目が 9 種（久米ほか 2008), 岡山県では造成後半年でカメムシ目が 9 種, コ ウチュウ目が 13 種（阪田・難波 2020）と報告されてい る. 本研究では造成した年の 8 月までにカメムシ目が 10 種,コウチュウ目が 14 種, 翌年 8 月までに同 12 種 と 15 種, さらにその翌年 8 月までに 14 種と 16 種, 最 終的に造成後の 3 年間でカメムシ目 14 種とコウチュウ 目 19 種が確認されている。また，中島ほか（2018）は 福岡県内の止水性湿地の生物多様性の健全度を水生昆虫 の種組成から調べる手法を考案しているが，これを用い て本結果を評価するとそのスコアは 3.18 点となり,こ
れは 4 段階で評価した中でもっとも良い「(I) とても豊 かな湿地環境」に該当する．以上の点から，休耕田を掘 削して造成した本ビオトープは, 生物多様性保全に大き く貢献したと考えられた。

\section{水生昆虫の種数を決定する要因}

水生昆虫類の種数は夏季に多く，冬季に少ないという 顕著な季節性がみられた。このことは，一般的に止水性 昆虫の調査やそれを用いた環境評価を行う上で, 調査時 期の設定がきわめて重要であることを示している.

種数と多様度指数 $H^{\prime}$ は定点 $\mathrm{B}$ で顕著に大きく, 定点 $\mathrm{D}$ で顕著に小さかった。定点 $\mathrm{B}$ は水系から独立した下 池の一部であり, 定点として設定した $1 \mathrm{~m}$ 四方の中に 岸際のごく浅い植生豊富な湿地から水深のある池部分ま で連続的に変化する環境構造を有している（Fig 1)。こ のような陸域から水域にかけて連続的に変化する移行带 （エコトーン）が生物多様性保全に重要である点につい てはよく知られているところであるが（嚴佐ほか 2003 ; 高橋ほか 2009 ; 日本湿地学会 2017), 本研究に おいてもその重要性が裏付けられた。一方で定点 D は 上池と水田を結ぶ水路に設定した流水環境の地点で, 種 数や多様度指数 $H^{\prime}$ は小さかったもののオナシカワゲラ 属 Nemoura sp., ヘイケボタル Luciola lateralis, トビケ ラ目 Trichoptera spp. 2 種はこの地点でのみ確認された ものであった。 また，カワニナSemisulcospira libertina の個体数も顕著に多かった。これらのことから, 生物多 様性保全を目的とした湿地ビオトープを造成する場合に は, 浅所から深所まで連続的に変化する移行带（エコト ーン）を伴う環境構造とともに，止水から流水にかけて の多様な流速環境をデザインすることが重要であると考 えられる。

\section{湿地ビオトープに出現した生物の由来}

本ビオトープはほほ陸地化した休耕地を掘削して水を ためたものであり, 本調査で確認された水生生物のほと んどはもともとその場にいたものではなく，近傍地に生 息していたものが移動してきたもの，あるいは沈水植物 では地中の埋土種子が発芽したものが由来と考えられる。 水生動物のうち両生類, 魚類, 甲殼類, 貝類はいずれも 飛翔ができないが，これらは本ビオトープに隣接する水 路や水田に生息することを確認しており，上流あるいは 下流の水系を伝って移動してきたものと考えられる，

また，水生昆虫類の多くは飛翔して本ビオトープに侵 入したものと考えられ，本調査において確認された水生 昆虫類（真水生のカメムシ目とコウチュウ目）のほぼ全 種が, $2 \mathrm{~km}$ 以内に存在する 3 つのため池で生息が確認 
されている種であった。調査を行った 2011 年 4 月から 2014 年 3 月の 3 年間において, 周辺のため池に生息し ながらビオトープに出現しなかった種は 12 種であった が，その後，コガムシは 2015 年に，マメガムシは 2019 年に,コオイムシは 2020 年にそれぞれ確認されている (中島未発表デー夕)。渡辺ほか（2019）は水田域に生 息する止水性昆虫が飛翔により移動する範囲を2 $3 \mathrm{~km}$ 程度と報告しており, 本調查結果はこの知見と一 致する。 その一方で, 周辺のため池での生息が確認され ているものの, ミヤケミズムシ, コバンムシ, クビボソ コガシラミズムシ，キイロコガシラミズムシ，ヒメコガ シラミズムシ, ツブゲンゴロウ, ルイスッブゲンゴロウ, チャイロマメゲンゴロウ，タマガムシの 9 種は現在に至 る造成後 10 年間に打いて本ビオトープで一切確認がさ れていない (中島未発表データ)。これらはいずれも比 較的水質が良好で水生植物が豊富なため池環境を好む種 であり（中島ほか 2020），比較的富栄養で浅い本ビオト ープの環境構造が生息に適していなかった可能性がある。 西城（2001）は隣接するため池と水田間で, 渡部（2016） は隣接する水田と明渠間で, その水生昆虫の種組成が大 きく異なることを報告している，以上から，新規に湿地 ビオトープを造成した場合にその生物相がどうなるのか は周辺環境の生物相に強く依存しており, 特に飛翔が可 能な水生昆虫類については周囲 $2 \sim 3 \mathrm{~km}$ に存在するた め池・水田の水生昆虫相の影響を強く受けるが, 同時に ビオトープそのものの環境構造も非常に重要であると考 えられる。

\section{侵略的な外来種と沈水植物相, 水生昆虫相の関係}

本調查では侵略的な外来種としてウシガエル，アメリ カザリガニ，スクミリンゴガイの 3 種が確認された。こ れら 3 種はいずれも造成から半年後の 2011 年 8～9 月 以降に出現しており, 本ビオトープ周辺の水田や水路に 多く生息していることから，水路や陸上を通って少しず つ移動・定着を行ったものと考えられる。このうちウシ ガエルは安定して確認されず，スクミリンゴガイは 2011 年の 10 月以降, アメリカザリガニは 2012 年の 7 月以降に個体数が増加した．外来種としてのアメリカザ リガニとスクミリンゴガイが生態系に与える影響につい ては多くの報告があるが，アメリカザリガニは水生の動 植物に対して (Anastacio et al. 2005 ; Nishijima et al. 2017)，スクミリンゴガイは湿生植物に対して（Carlsson et al. 2004 ; 日鷹ほか 2007), それぞれ食害や切断によ る悪影響を与えることが報告されている。本調査でも特 にこれら 2 種の外来種による悪影響を受けたと考えられ
るのが沈水植物で, 本ビオトープを造成した 2011 年の 7 月から 11 月にかけてミズオオバコとキクモを中心と した大群落が下池に出現したが（Fig. 7a)，翌 2012 年の 同一時期にはこの群落は出現せず岸際にわずかにキクモ が生育するのみであった（Fig. 7b)，これら沈水植物が 発芽するのは 6 月頃であること, 2011 年 6 月にはアメ リカザリガニ，スクミリンゴガイともに確認されておら ず，翌年の 2012 年 6 月にはすでにこの 2 種が確認され ていたこと，本ビオトープで採集し研究室で栽培を続け ているミズオオバコ, キクモ，イトトリゲモが，水抜き 等の処置を行わずとも2020 年現在, 毎年発芽・生育し ていること（中島未発表データ），さらに前述したよう に2013 年に採取した底泥には除草剤を含む農薬類の影 響はみられなかったこと，以上の 4 点から考えると，沈 水植物の種数 - 個体数の減少は, 2011 年秋以降に定着 したアメリカザリガニとスクミリンゴガイの増加に伴う 食害によるものである可能性が高い。なお，2013 年 7 8 月には下池でキクモが群落を形成したが，この年は 4 〜 6 月にかけて下池が干上がっており，これにより一時 的にアメリカザリガニとスクミリンゴガイが全滅し食害 されなかったことが理由と考えられる。

また, 水生昆虫類の種数がもっとも多い夏季 (8月) について, 真水生のカメムシ目・コウチュウ目の合計種 数は 2011 年が 18 種, 2012 年が 16 種, 2013 年が 14 種 と年を追うごとにわずかながら減少していった，湿地ビ オトープに扔ける経年の種数の減少については田中ほか （2013）がすでに指摘しているところであり，その理由 として水路や池の水底に泥が堆積すること, 水生植物の 種数が減少することを挙げている，本調査に扔いても水 深はその 3 年間で顕著に浅くなっており, 水生植物が減 少したことから，同様の現象が生じていたものとも考え られる，ただし，田中ほか（2013）の調査では造成後 4 年程度は種数が増加しており, 一方で本ビオトープの種 数は 2 年目から減少していることからその傾向は大きく 異なる. 先行研究と本ビオトープの間の環境構造には大 きな違いがあり，単純に比較することはできないが，本 ビオトープでは前述したように水質環境には大きな制限 要因はなかったと考えられることから，本ビオトープに 扔ける水生昆虫類の種数が 2 年目以降減少傾向を示した ことは, 沈水植物の急速な減少, そしてアメリカザリガ ニとスクミリンゴガイの 2 種の外来種の増加と関倸があ るかもしれない.

以上, 本調查結果から, 休耕地に造成した湿地ビオト ープは生物多様性保全に大きく貢献することが明らかで 
あり,より高い成果を出すためには移行带（エコトー ン）と流速の 2 点に注目した多様な環境構造を創出する ようなデザインが重要であるものと考えられた。同時に その生物相は周辺環境に生息する種に大きく影響を受け ること, 特にアメリカザリガニとスクミリンゴガイの 2 種の外来種の管理に注意する必要があることなどが明ら かとなった，水田域の生物相は地域によって大きく異な ることから, 今後も各地で同様な調査がなされ，生物多 様性保全により効果のある湿地ビオトープのデザイン, 管理手法などについての知見が蓄積されることが望まれ る.

\section{謝 辞}

本研究を実施するにあたり，種同定等でご教示いただ いた福岡県保健環境研究所の緒方 健氏, 須田隆一氏, 石間妙子氏，どじょうクラブの野中繁孝氏，本ビオトー プの調査に便宜を図っていただいた福岡県宗像・遠賀保 健福祉環境事務所, 福岡県自然環境課に厚くお礼申し上 げる。

\section{摘 要}

1. 休耕田を掘削した湿地ビオトープ（手光ビオトープ） における 3 年間の調査において, 18 目 93 種の水生動物, 4 種の沈水植物を確認した。このうち環境省あるいは福 岡県レッドデータブック掲載種は 24 種であり, 本ビオ トープが生物多様性や希少種の保全に効果があったこと がわかった。

2. 水生昆虫の種数は夏季（8月）を中心とした時期に 増加, 冬季（2月）を中心とした時期に減少し, 顕著な 季節性があることがわかった。このことから，止水性昆 虫相の調查は夏季に行うことが適していると考えられた。 3. 水生昆虫の種数及び多様度指数 $\left(H^{\prime}\right)$ は顕著な移行 帯（エコトーン）をもつ地点が大きかったが, 一方で流 水環境に特異な種も確認されたことから, 生物多様性保 全を目的とした場合には浅所から深所まで連続的に変化 する移行带を伴う環境構造とともに, 止水から流水にか けての多様な流速環境をデザインすることが重要である と考えられた。

4. 本ビオトープで確認された水生昆虫類は, ほぼ全種 が近隣の $2 \mathrm{~km}$ 以内のため池に生息する種であったが, その一方でそれらのため池に生息しながらビオトープで 確認されない種もあった。このことから，本ビオトープ
の水生昆虫相は, 周囲の水生昆虫相とビオトープの環境 構造の 2 点から決定したものと考えられた。

5. 本ビオトープの水生生物相は侵略性のある外来種で あるアメリカザリガニとスクミリンゴガイによる悪影響 を受けていたものと考えられた。

\section{引用文献}

Anastacio P.M., Parente V.S. \& Correia, A.M. (2005) Crayfish effects on seeds and seedlings: identification and quantification of damage. Freshwater Biology 50: 697-704.

Carlsson N.O.L, Brönmark C. \& Hansson L-A. (2004) Invading herbivory: The golden apple snail alters ecosystem functioning in Asian wetlands. Ecology 85: 1575-1580.

Dudgeon D., Arthington A.H., Gessner M.O., Kawabata Z.I., Knowler D.J., Lévêque C., Naiman R.J., Prieur-Richard A.H., Soto D., Stiassny M.L.J. \& Sullivan C.A. (2006) Freshwater biodiversity: importance, threats, status and conservation challenges. Biological Reviews 81: 163-182.

福岡県（2014）福岡県の希少野生生物：福岡県レッドデータ ブック 2014. 福岡県, 福岡.

福岡県宗像・遠賀保健福祉環境事務所 (2019) 手光ビオトー プ〜きて, みて, さわって〜。福岡県宗像・遠賀保健福祉 環境事務所, 宗像.

グリーンインフラ研究会（2020）実践版! グリーンインフラ. 日経 BP，東京。

日鷹一雅・嶺田拓也・徳岡美樹（2007） スクミリンゴガイ Pomacea canaliculata (Lamarck) の侵入が水田植物相に及 ぼす影響. 農村計画学会誌 26: 233-238.

市川憲平（2004）放棄田ビオトープによる里の自然再生と夕 ガメやその他の水生動物の定着. ホシザキグリーン財団研 究報告 7: 137-150.

市川憲平（2009）止水性水生昆虫の現状 2008. 昆虫と自然 $44(1): 2-4$.

井上大輔 · 福岡県立北九州高等学校魚部 · 北九州市響灘ビオ トープ (2013) 響灘ビオトープの水辺の生きもの. 福岡県 立北九州高等学校魚部, 北九州市.

Ito H.C., Shiraishi H., Nakagawa M. \& Takamura N. (2020) Combined impact of pesticides and other environmental stressors on animal diversity in irrigation ponds. PLoS ONE 15(7): e0229052.

嚴佐庸 · 松本英夫 · 菊沢喜八郎 - 日本生態学会（2003）生態 学事典. 共立出版, 東京.

Jänsch S., Frampton G.K., Römbke J.Van Den Brink P.J. \& Scott-Fordsmand J.J. (2006) Effects of pesticides on soil invertebrates in model ecosystem and field studies: a review and comparison with laboratory toxicity data. Environmental Toxicology and Chemistry 25(9): 2490-2501.

角野康郎（2014） ネイチャーガイド日本の水草. 文一総合出 版, 東京.

環境省（2014）生物多様性の観点から重要度の高い湿地 (http://www.env.go.jp/nature/important_wetland/index.html, 2020 年 8 月 1 日確認).

環境省（2015）生態系被害防止外来種リスト（https://www. env.go.jp/nature/intro/2outline/iaslist.html, 2020 年 8 月 1 日確認). 
環境省（2019）別表 2 生活環境の保全に関する環境基準（湖 沼）（https://www.env.go.jp/kijun/wt2-1-2.html，2020 年 8 月 1 日閲覧).

環境省（2020）環境省レッドリスト 2020（http://www.env.go. jp/press/files/jp/114457.pdf, 2020 年 8 月 1 日閲覧).

Kasai A., Hayashi T.I., Ohnishi H., Suzuki K., Hayasaka D. \& Goka K. (2016) Fipronil application on rice paddy fields reduces densities of common skimmer and scarlet skimmer. Scientific Reports 6: 23055.

川合禎次 ·谷田一三（2018） 日本産水生昆虫第二版：科 · 属・種への検索。東海大学出版部, 神奈川。

北村泰一（2008）耕作放棄水田等を利用した水生昆虫ビオト ープネットワーク構築の可能性. 南九州大学研究報告 38A: 47-59.

北野忠 · 唐真盛人 · 水谷晃 · 崎原健 · 河野裕美 (2011) 西表 島におけるゲンゴロウ類の生息状況．東海大学沖縄地域研 究センター所報 2010: 37-43.

久米幸毅 - 池ノ上竜太 - 奥村和也 - 稲本雄太 - 北川忠生 - 久 保喜計・細谷和海（2008）近畿大学田んぼビオトープに見 られる水生生物。近畿大学農学部紀要 41: 135-167.

松井明・増田栄之 (2018) 和田ビオトープ (福井県高浜町) の設計およびモニタリング調査. 応用生態工学 20: 221229

宮下直・野田隆史（2003）群集生態学. 東京大学出版会, 東 京.

宮脇崇 · 飛石和大 · 竹中重幸 ·門上希和夫（2013）マイクロ ウェーブ抽出を用いる土畩中有機污染物質のスクリーニン グ法の開発. 分析化学 62: 971-978.

水谷正一 (2007) 水田生態工学入門. 農文協, 東京.

Moore P.D. (2006) Wetlands. Chelsea House, Hong Kong.

中島淳（2013）過去から現在における水生甲虫相の変遷〜福 岡県での事例〜。昆虫と自然 48(4): 16-19.

中島淳（2020）日本産水生コウチュウ目の最新情報. 昆虫と 自然 55(9): 4-7.

中島淳 · 林成多 - 石田和男 · 北野忠 - 吉富博之 (2020) 齐イ チャーガイド日本の水生昆虫，文一総合出版，東京，

中島淳・ 中村晋也·大平裕 (2012) 福岡県福津市に造成した ビオトープにおけるカスミサンショウウオの産卵事例。九 州両生爬虫類研究会誌 3: 46-48.

中島淳 ·上野由里代 ·井上大輔 · 須田隆一（2018）水生昆虫 類を用いた平均スコア法による止水性湿地の生物多様性指 標. 福岡県保健環境研究所年報 45: 61-65.

Nakanishi K., Yokomizo H. \& Hayashi T.I. (2018) Were the sharp declines of dragonfly populations in the 1990s in Japan caused by fipronil and imidacloprid? An analysis of Hill's causality for the case of Sympetrum frequens. Environmental Science and Pollution Research 25: 35352-35364.

日本湿地学会 (2017) 図説 日本の湿地人と自然と多様な 水辺. 朝倉書店, 東京.

西原昇吾 (2016) 総論 水生昆虫の危機的生息現状と実践的 な保全. 昆虫と自然 51 (7): 2-4.

西廣淳 · 大槻順朗 - 高津文人 · 加藤大輝 - 小笠原奨悟 - 東海 林太郎・長谷川雅美・近藤昭彦 (2020)「里山グリーンイ ンフラ」による気候変動適応：印旛沼流域における谷津の 耕作放棄田の多面的活用の可能性. 応用生態工学 22: 175185.

Nishijima S., Nishikawa C. \& Miyashita T. (2017) Habitat modi- fication by invasive crayfish can facilitate its growth through enhanced food accessibility. BMC Ecology 37: DOI 10.1186/ s12898-017-0147-7.

農林水産省（2012）農林水産省生物多様性戦略（https://www maff.go.jp/j/kanbo/kankyo/seisaku/s_senryaku/pdf/senryaku. pdf, 2020 年 8 月 1 日確認)

農林水産省 (2019) 作物統計調査/面積調査 長期累年(https:/ www.e-stat.go.jp/stat-search/file-download?statInfId=0000 $31889370 \&$ fileKind $=0,2020$ 年 8 月 1 日確認).

農林水産省農林水産技術会議事務局（2012）農業に有用な生 物多様性の指標生物調査・評価マニュアル（http://www naro.affrc.go.jp/archive/niaes/techdoc/shihyo/, 2020 年 8 月 1 日確認)

鬼倉徳雄 · 中島淳 · 林博徳 ·西山穏 (2020) 水田・水路でつ なぐ生物多様性ポイントブック。公益財団法人世界自然保 護基金ジャパン，東京.

大野豊・高橋剛一郎（2009）富山県立大学水田跡地のビオ卜 ープに関する調査・研究— 2 : ビオトープ化初期の昆虫相 一. 富山県立大学紀要 20: 58-64.

尾園暁・川島逸郎・二橋亮（2012） ネイチャーガイド日本の トンボ。文一総合出版, 東京.

Reid A.J., Carlson A.K., Greed I.F., Eliason E.J., Gell P.A., Johnson P.T.J., Kidd K.A., MacCormack T.J., Olden J.D., Ormerod S.J., Smol J.P., Taylor W.W., Tockner K., Vermaire J.G., Dudgeon D. \& Cooke S.J. (2019) Emerging threats and persistent conservation challenges for freshwater biodiversity. Biological Reviews 94: 849-873.

阪田睦子・難波靖司（2020）岡山県自然保護センター水田ビ オトープにおける植物及び水生動物調査. 岡山県自然保護 センター研究報告 $27: 23-42$.

西城洋（2001）島根県の水田と溜め池に扮ける水生昆虫の季 節的消長と移動. 日本生態学会誌 51: 1-11.

須田達也（2010）水田跡地に創出した湿地ビオトープの機能 一生物多様性保全と水質浄化機能の評価一。農業㧍よび園 芸 85: 425-434.

高橋剛一郎 · 寒川剛 · 石田雅大 · 赤座久明 (2010) 富山県立 大学水田跡地のビオトープに関する調査・研究—3：ビオ トープと周辺の哺乳動物一. 富山県立大学紀要 20: 61-65.

高橋裕 · 岩屋隆夫 ·沖大幹 - 島谷幸宏 - 寶馨 - 玉井信行 . 野々村邦夫 ·藤芳素生 (2009) 川の百科事典，丸善株式会 社, 東京.

竹内真一 ·成富勝 - 南風原武史 · 谷水翔 · 友納早苗 · 安田 繁・丸居篤・宇根豊（2009）大学構内におけるビオトープ の創出活動と小水田における生き物調査。造園技術報告集 5: 60-63

田中幸一・浜崎健児・松本公吉 - 鎌田輝志 (2013) 造成され たビオトープにおける水生昆虫の種数の変化. 昆蟲（二ュ ーシリーズ) 16: 189-199.

田和康太 · 佐川志朗 · 宮西萌 · 細谷和海 (2019) 川域から水 田域までのエコロジカルネットワーク形成による水田魚類 群集の生息場所および再導入コウノトリCiconia boyciana の採餌環境の保全. 日本鳥学会誌 68: 193-208.

宇根豊 (2016) 農本主義のすすめ。ちくま新書, 東京.

渡部晃平 (2016) 愛媛県南西部の水田における明渠と本田間 の水生昆虫（コウチュウ目・カメムシ目）の分布。保全生 態学研究 21: 227-235.

渡辺黎也 · 日石下碧・横井智之（2019）水田内の環境と周辺 
の景観が水生昆虫群集（コウチュウ目・カメムシ目）に与 える影響. 保全生態学研究 24: 49-60.

養父志乃夫 (2005) 田んぼビオトープ入門. 農文協, 東京.

山下寿之 · 大原隆明 - 中田政司 · 高橋剛一郎 (2009) 富山県
立大学水田跡地のビオトープに関する調査・研究一1：ビ オトープ化初期の植生と植物相一. 富山県立大学紀要 19 : 49-57. 